\title{
Dietary Fibre and Energy Consumption as Predictors of Anthropometric Parameters in a Youthful Male Population: A Cross-sectional Study in Sissala East
}

\author{
Sufyan Bakuri Suara \\ Department of Population and Reproductive Health, School of Public Health, University for Development Studies, Tamale, Ghana
}

Email address:

suara.ghana@yahoo.com

\section{To cite this article:}

Sufyan Bakuri Suara. Dietary Fibre and Energy Consumption as Predictors of Anthropometric Parameters in a Youthful Male Population: A Cross-sectional Study in Sissala East. American Journal of Health Research. Vol. 9, No. 2, 2021, pp. 50-56. doi: 10.11648/j.ajhr.20210902.14

Received: April 9, 2021; Accepted: April 26, 2021; Published: May 14, 2021

\begin{abstract}
Background: Despite the significant role of fiber and energy consumption in the development of overweight and obesity, associations between these dietary measures and the prevalence of obesity in Ghana are lacking. Hence, the objective of the survey was to determine a relationship between fiber and energy and the odds of obesity among a young male population from Sissala East Municipal. Methods: The present cross-sectional study was conducted using a randomly recruited 406 young male population (aged 20-29 years) in Sissala Municipality. Data were collected in November and December 2020. Dietary fiber and energy were obtained from the West African Food composition tables. Quantities of food consumed were assessed by using a 24-hour dietary recall approach. The proxies for general obesity and abdominal obesity were body mass index and waist circumference, respectively. Before data collection, permission was sought from the Municipal Health Directorate, and traditional heads in the communities. Results: In the unadjusted binary logistic regression models, the odds of general and abdominal obesity were significantly lower in the higher quartiles of dietary fiber, compared with quartile-one. Similarly, in the adjusted model, in which the effects of age, household size of the respondent, education, occupation, and marital were adjusted, there was still a significant inverse relationship between dietary fiber and the odds of general and abdominal obesity. Conversely, there was a significant positive association between dietary energy intake and the odds of general and abdominal obesity in both the unadjusted and adjusted models. Conclusion: From the findings, dietary fiber and energy were inversely and positively related to obesity [both general and abdominal], respectively. The intake of fiber rich diets might be beneficial for the prevention of obesity and ought to be promoted by the nutrition and health authorities.
\end{abstract}

Keywords: Fiber, Energy, General Obesity, Abdominal Obesity, Overweight

\section{Background}

In developing countries $[1,2]$, consumption of added sugars including diets that low in fiber is on the rise, concurrent with a high trend of obesity [1]. Previously, in Ghana, dietary energy is mainly obtained from refined grain products [3], which are low in dietary fiber. Although total daily energy intake in the country has been estimated to about 2295-2619 kcals per day [4], data on dietary fiber intake are scarce. Moreover, the relationships between obesity and dietary energy and fiber are limited. Notwithstanding, various studies have estimated the prevalence of obesity in the country. For example, a previous review suggests that $43 \%$ of adult Ghanaians are either obese or overweight [5].

Globally, obesity is linked to a higher mortality rate and several health conditions including metabolic syndrome, and various cancers [6-8]. Therefore, several efforts ought to be taken to reverse the increasing trends of obesity. The consumption of dietary fiber has a lot of health benefits [9, 10, 19, 11-18]. In line with this, the relationships between dietary fiber and body weight have received considerable 
attention in nutrition research. Dietary fiber consumption delays intestinal transit, improves insulin sensitivity, and helps in the regulation of lipid oxidation to benefit body weight maintenance [20-22]. Furthermore, consumption of dietary fibers is linked with prolonged satiety hence, prevents the likelihood of excessive dietary energy ingestion [23, 24]. Additionally, numerous observational studies reported inverse associations between obesity and dietary fiber intake [25-31], however, in one study, a null association was reported [32].

Further, diets low in energy are associated with increased satiety [33] thus, a protective mechanism against obesity. However, additional data are required to clarify the relationship between energy intake and the odds of obesity because there are conflicting reports in the literature. For instance, in 5 observational studies, a positive association between energy intake and obesity was reported [34-38]. Also, a positive association between waist circumference and dietary energy intake was found [34, 38]. In contrast, in another study, energy intake did not show a significant association either with body mass index or waist circumference [39]. The relationships between dietary energy and fiber consumption and obesity are lacking in Ghana. The present results may not only be useful for the formulation of strategies to reverse the increasingly high prevalence of obesity in the country but will also bridge a longstanding research gap. The objective of the study was to assess the associations between dietary fiber and energy consumption and odds of obesity among a young male population from Sissala Eats, Ghana.

\section{Methods and Materials}

\subsection{Study Design and Participants}

In the present cross-sectional study, 406 young males (aged 20-29 years) were simple randomly selected. The sample size was based on standardized criteria for computing sample size in cross-sectional studies [40]. The participants were drawn from 5 communities [Tumu, Sakai, Kulfuo, Wallembelle, and Bugubelle] in Sissala East Municipality, Upper West Region, Ghana. Data were collected in November and December 2020. Participation in the survey was purely voluntary. Persons with known impaired health conditions that can affect the relationship between diet and obesity measures were excluded. For instance, a few potential respondents mentioned severe nausea and malaria hence, they were excluded from the study.

\subsection{Lifestyle and Sociodemographic Factors}

Data were collected on demographic variables [household assets, occupation, age, household size marital status, parity, educational status, and physical activity] by using structured questionnaires through face-to-face interviews. The economic status of participants' households was examined by collecting data on household assets ownership. A list of assets owned by a respondent household was enumerated. Also, the make-up of the rooms [made of cow dung, thatch, cement, tiles, and zinc] was inspected. From the above assets and the room makeup indicators, a proxy index was calculated to reflect the wealth status of the household from which the respondent was recruited. Additionally, the physical activity (PA) of participants was assessed using the international PA questionnaire short form [41]. Results from a previous study show the international PA questionnaires are valid for use across different cultures [42]. With these questionnaires, the duration in minutes and number of days within the previous week a person spent doing moderate-intensity and vigorous-intensity activities and walking were recorded. The overall PA (MET-minutes/week) was calculated by adding up the sub-totals for moderate, vigorous, and walking activities. Further, dietary energy and fiber were obtained from the West African Food composition table [43]. To enhance the quality of dietary recall, a multiple-pass approach was employed [44, 45].

\subsection{Anthropometric Assessment}

A German-made Seca weighing scale (serial number (1881017060375) was used to measure body weight $(\mathrm{kg})$. Also, a United Nations Children Emergency Fund height board was used to evaluate the height $(\mathrm{cm})$ of participants. Body mass index was derived from the ratio of weight $(\mathrm{kg})$ to height $\left(\mathrm{m}^{2}\right)$. The absence of overweight/general obesity was considered as a body mass index $\leq 24.9 \mathrm{~kg} / \mathrm{m}^{2}$. Also, the presence of overweight/obesity was considered to be body mass index of $\geq 25 \mathrm{~kg} / \mathrm{m} 2$ [46]. A non-stretchable fiber-glass tape was used to measure waist circumference according to the World Health Organization standards [47]. Abdominal obesity was defined based on the International Diabetes Federation recommendation thus, waist circumference $\geq 94$ $\mathrm{cm}[7,48]$.

\section{Results}

Table 1 below represents the characteristics of participants according to obesity based on body mass index (a proxy for general obesity). Averagely, participants without obesity or overweight were significantly $(\mathrm{P}=0.002)$ younger than participants with overweight or obesity thus, $23.73 \pm 2.59$ years and $24.53 \pm 2.58$ years, respectively. Moreover, higher quartiles of dietary fiber $(\mathrm{P}<0.001)$ were significantly associated with normal body weight. However, a higher proportion of participants with either overweight or obesity were classified under the highest quartile of dietary energy, when compared with participants without either overweight/obesity $(\mathrm{P}<0.001)$. In contrast, the study failed to reveal a significant difference in household size, education, occupation, marital status, and ethnicity among participants who were obese and those who were not obese. 
Table 1. Characteristics of participants according to obesity based on body mass index.

\begin{tabular}{|c|c|c|c|c|}
\hline \multirow{2}{*}{ Variables } & \multicolumn{3}{|c|}{ Overweight and Obesity Present } & \multirow{2}{*}{ P-value } \\
\hline & Frequency & No $(n=241)$ & Yes $(n=165)$ & \\
\hline Age (years & 406 & $23.73 \pm 2.59$ & $24.53 \pm 2.58$ & $0.002^{* *}$ \\
\hline Household size & 406 & $8.04 \pm 6.24$ & $7.03 \pm 5.32$ & $0.090^{* *}$ \\
\hline \multicolumn{5}{|l|}{ Education } \\
\hline At most primary & 326 & $192(58.9)$ & $134(41.1)$ & $0.800^{*}$ \\
\hline At least junior high & 80 & $49(61.3)$ & $31(38.8)$ & \\
\hline \multicolumn{5}{|l|}{ Occupation } \\
\hline Farming and trading & 343 & $200(58.3)$ & $143(41.7)$ & $0.332^{*}$ \\
\hline Salary worker & 63 & $41(65.1)$ & $22(34.9)$ & \\
\hline \multicolumn{5}{|l|}{ Marital Status } \\
\hline Married & 89 & $195(61.5)$ & $122(38.5)$ & \\
\hline Single & 317 & $46(51.7)$ & $43(48.3)$ & $0.112^{*}$ \\
\hline \multicolumn{5}{|l|}{ Ethnicity } \\
\hline Sissala & 350 & $204(58.3)$ & $146(41.7)$ & \\
\hline Dagaaba & 25 & $18(72.0)$ & $7(28.0)$ & $0.359^{\ddagger}$ \\
\hline Kasina/Gurusi & 14 & $7(50.0)$ & $7(50.0)$ & \\
\hline Others (Ashanti, Frafra, Kusasi) & 17 & $204(58.3)$ & $146(41.7)$ & \\
\hline \multicolumn{5}{|l|}{ Fiber (g/day) } \\
\hline Quartile-one & 101 & $42(41.6)$ & $59(58.4)$ & \\
\hline Quartile-two & 102 & $64(62.7)$ & $38(37.3)$ & $\mathrm{P}<0.001^{*}$ \\
\hline Quartile-three & 102 & $59(57.8)$ & $43(42.2)$ & \\
\hline Quartile-four & 101 & $76(75.2)$ & $25(24.8)$ & \\
\hline \multicolumn{5}{|l|}{ Energy (kcal/day) } \\
\hline Quartile-one & 101 & $76(75.2)$ & $25(24.8)$ & \\
\hline Quartile-two & 102 & $59(57.8)$ & $43(42.2)$ & $\mathrm{P}<0.001^{\ddagger}$ \\
\hline Quartile-three & 102 & $64(62.7)$ & $38(37.3)$ & \\
\hline Quartile-four & 101 & $42(41.6)$ & $59(58.4)$ & \\
\hline
\end{tabular}

"Pearson Chi-Square; ${ }^{*}$ Fisher's Exact Test (in 2 by 2 table); ${ }^{* *}$ Independent-Samples T-Test; P $<0.05$ means significant association. Overweight and Obesity [body mass index $\geq 25 \mathrm{kgm}^{-2}$ ].

Table 2. Characteristics of participants according to obesity based on waist circumference.

\begin{tabular}{|c|c|c|c|c|}
\hline \multirow{2}{*}{ Variables } & \multicolumn{3}{|c|}{ Overweight and Obesity Present } & \multirow{2}{*}{ P-value } \\
\hline & Frequency & No $(n=221)$ & Yes $(n=185)$ & \\
\hline Age (years & 406 & $23.85 \pm 2.62$ & $24.30 \pm 2.60$ & $0.084^{* *}$ \\
\hline Household size & 406 & $7.83 \pm 6.25$ & $7.39 \pm 5.44$ & $0.451^{* *}$ \\
\hline \multicolumn{5}{|l|}{ Education } \\
\hline At most primary & 326 & $176(54.0)$ & $150(46.0)$ & $0.802^{*}$ \\
\hline \multicolumn{4}{|l|}{ Occupation } & \\
\hline Farming and trading & 343 & $180(52.5)$ & $163(47.5)$ & $0.074^{*}$ \\
\hline Salary worker & 63 & $41(65.1)$ & $22(34.9)$ & \\
\hline \multicolumn{5}{|l|}{ Marital Status } \\
\hline Married & 89 & $177(55.8)$ & $140(44.2)$ & $0.335^{*}$ \\
\hline Single & 317 & 4449.4) & $45(50.6)$ & \\
\hline \multicolumn{5}{|l|}{ Ethnicity } \\
\hline Sissala & 350 & $188(53.7)$ & $162(46.3)$ & \\
\hline Dagaaba & 25 & $15(60.0)$ & $10(40.0)$ & $0.748^{\ddagger}$ \\
\hline Kasina/Gurusi & 14 & $7(50.0)$ & $7(50.0)$ & \\
\hline Others (Ashanti, Frafra, Kusasi) & 17 & $11(64.7)$ & $6(35.3)$ & \\
\hline \multicolumn{5}{|l|}{ Fiber (g/day) } \\
\hline Quartile-one & 101 & $36(35.6)$ & $65(64.4)$ & \\
\hline Quartile-two & 102 & $58(56.9)$ & $44(43.1)$ & $\mathrm{P}<0.001^{\ddagger}$ \\
\hline Quartile-three & 102 & $53(52.0)$ & $49(48.0)$ & \\
\hline Quartile-four & 101 & $74(73.3)$ & $27(26.7)$ & \\
\hline \multicolumn{5}{|l|}{ Energy (kcal/day) } \\
\hline Quartile-one & 101 & $74(73.3)$ & $27(26.7)$ & \\
\hline Quartile-two & 102 & $53(52.0)$ & $49(48.0)$ & $\mathrm{P}<0.001^{\ddagger}$ \\
\hline Quartile-three & 102 & $58(56.9)$ & $44(43.1)$ & \\
\hline Quartile-four & 101 & $36(35.6)$ & $65(64.4)$ & \\
\hline
\end{tabular}

\$Pearson Chi-Square; * Fisher's Exact Test (in 2 by 2 table); ${ }^{* *}$ Independent-Samples T-Test; $\mathrm{P}<0.05$ means significant association. Overweight and Obesity [waist circumference $\geq 94 \mathrm{~cm}$ ]. 
Table 2 illustrates the characteristics of participants according to obesity status based on waist circumference (a proxy for abdominal obesity). The results revealed an inverse association between abdominal obesity and dietary fiber $(\mathrm{P}<$ 0.001). Conversely, energy showed a positive association with abdominal obesity $(\mathrm{P}<0.001)$. The study failed to support a relationship between participants' obesity and age, household size, education, occupation, marital status, and ethnicity.

Table 3 below outlines the results of binary logistic regression predicting the odds of general obesity with respect to quartiles of dietary fiber and energy. In the unadjusted model, the odds of general obesity were significantly lower in the higher quartiles of fiber intake, compared with the quartile-one. Similarly, in the adjusted model, in which the effects of age, respondent, household size of the respondent, education, occupation, and marital were adjusted, there was still a significant inverse relationship between dietary fiber and the odds of general obesity.

Further, there was a positive association between energy intake and the odds of general obesity. For example, the odds of overweight and general obesity were significantly higher among participants classified under the fourth quartile when compared with those classified under the quartile-one [4.27 (2.34-7.79); $\mathrm{P}<0.001]$. Moreover, the relationship was still significant upon an adjustment for the effects of age, respondent, household size of the respondent, education, occupation, and marital were adjusted, there was still a significant inverse relationship between dietary fiber intake and the odds of overweight and abdominal obesity [4.58 (2.44-8.58); $\mathrm{P}<0.001]$.

Table 3. Odds of general obesity according to quartiles of dietary fiber and energy intake.

\begin{tabular}{|c|c|c|c|c|}
\hline \multirow{2}{*}{ Predictor } & \multicolumn{2}{|c|}{ Unadjusted model } & \multicolumn{2}{|l|}{ Adjusted model } \\
\hline & OR (95\%CI) & P-value & OR (95\%CI) & P-value \\
\hline \multicolumn{5}{|l|}{ Fiber (g/day) } \\
\hline Quartile-one $(n=101)$ & Reference & & & \\
\hline Quartile-two $(n=102)$ & $0.42(0.24-0.74)$ & 0.003 & $0.44(0.24-0.80)$ & 0.008 \\
\hline Quartile-three $(n=102)$ & $0.52(0.30-0.91)$ & 0.021 & $0.52(0.29-0.93)$ & 0.029 \\
\hline Quartile-four $(\mathrm{n}=101)$ & $0.23(0.13-0.43)$ & $\mathrm{P}<0.001$ & $0.22(0.12-0.41)$ & $\mathrm{P}<0.001$ \\
\hline \multicolumn{5}{|l|}{ Energy (kcal/day) } \\
\hline Quartile-two $(n=102)$ & $2.22(1.22-4.03)$ & 0.009 & $2.36(1.28-4.36)$ & 0.006 \\
\hline Quartile-three $(n=102)$ & $1.81(0.99-3.30)$ & 0.055 & $1.99(1.06-3.74)$ & 0.032 \\
\hline Quartile-four $(n=101)$ & $4.27(2.34-7.79)$ & $\mathrm{P}<0.001$ & $4.58(2.44-8.58)$ & $\mathrm{P}<0.001$ \\
\hline
\end{tabular}

n: number of participants classified under the quintile; OR: Odds Ratios; Overweight and Obesity defined as body mass index $\geq 25$ kgm ${ }^{-2}$; Adjusted model: adjusted for the effects of age of respondent, household size of respondent, education, occupation, marital status dichotomized. Q: quartile. Binary logistic repressions model was used to assess odds general obesity.

Table 4 below outlines the odds of abdominal obesity according to quartiles $(\mathrm{Q})$ of dietary fiber and energy. In the unadjusted model, the odds of overweight and abdominal obesity were significantly lower in the higher quartiles of fiber intake, when compared with the quartile-one. Similarly, in the adjusted model, in which the effects of age, respondent, household size of the respondent, education, occupation, and marital were adjusted, there was still a significant inverse relationship between dietary fiber intake and the odds of overweight and abdominal obesity.

Table 4. Odds of abdominal obesity/overweight according to quartiles $(Q)$ of dietary fiber and energy intake.

\begin{tabular}{|c|c|c|c|c|}
\hline \multirow{2}{*}{ Predictor } & \multicolumn{2}{|c|}{ Unadjusted model } & \multicolumn{2}{|l|}{ Adjusted model } \\
\hline & OR $(95 \% \mathrm{CI})$ & P-value & OR $(95 \% \mathrm{CI})$ & P-value \\
\hline \multicolumn{5}{|l|}{ Fiber (g/day) } \\
\hline Quartile-one $(n=101)$ & Reference & & & \\
\hline Quartile-two $(\mathrm{n}=102)$ & $0.42(0.24-0.74)$ & 0.003 & $0.41(0.23-0.76)$ & 0.005 \\
\hline Quartile-three $(\mathrm{n}=102)$ & $0.51(0.29-0.90)$ & 0.020 & $0.49(0.27-0.88)$ & 0.018 \\
\hline Quartile-four $(\mathrm{n}=101)$ & $0.20(0.11-0.37)$ & $\mathrm{P}<0.001$ & $0.19(0.10-0.35)$ & $\mathrm{P}<0.001$ \\
\hline \multicolumn{5}{|l|}{ Energy (kcal/day) } \\
\hline Quartile-one $(\mathrm{n}=101)$ & Reference & & & \\
\hline Quartile-two $(\mathrm{n}=102)$ & $2.53(1.41-4.56)$ & 0.002 & $2.59(1.43-4.70)$ & 0.002 \\
\hline Quartile-three $(n=102)$ & $2.08(1.15-3.75)$ & 0.015 & $2.20(1.19-4.05)$ & 0.011 \\
\hline Quartile-four ( $\mathrm{n}=101$ ) & $4.95(2.72-9.02)$ & $\mathrm{P}<0.001$ & $5.31(2.84-9.94)$ & $\mathrm{P}<0.001$ \\
\hline
\end{tabular}

n: number of participants classified under the quintile; OR: Odds Ratios; Overweight and Obesity defined as waist circumference $\geq 94 \mathrm{~cm}$; Adjusted model: adjusted for the effects of age of respondent, household size of respondent, education, occupation, marital status dichotomized; Q: quartile. Binary logistic repressions model was used to assess odds abdominal obesity

Generally, a positive relationship between energy intake and the odds of abdominal obesity was observed. Specifically, the odds of overweight and abdominal obesity were significantly higher in participants classified under the fourth quartile when compared with those classified under the quartile-one [4.95 (2.72-9.02); $\mathrm{P}<0.001]$. The relationship 
was still significant upon an adjustment for the effects of age, respondent, household size of the respondent, education, occupation, and marital were adjusted, there was still a significant inverse relationship between dietary fiber intake and the odds of overweight and abdominal obesity [5.31 (2.84-9.94); $\mathrm{P}<0.001]$.

\section{Discussion}

In most Sub-Saharan African nations, there is an increase in added sugar consumption parallel to a high prevalence of obesity [1]. Although there are no direct studies in Ghana which evaluated the associations between fiber intake and the odds of obesity, the intake of refined cereal and grain products was found to increase the risk of abdominal obesity among University students [49]. These refined cereal and grain products are not only low in dietary fiber concentration but are also high glycemic index products [50].

In line with the inverse relationships between dietary fiber and general and abdominal obesity as found in the present study, 3 previous cross-sectional studies conducted in Egypt [25], Belgium [26], and Finland [27] reported similar results. Moreover, in a meta-analysis of randomized clinical trials among overweight and obese adults, dietary fiber supplementation when compared with the placebo caused significant reductions in body fat and body mass index [28]. Several mechanisms may have explained the favorable body weight measurements associated with the intake of dietary fiber. For instance, dietary fiber consumption is linked with a delay in intestinal transit and helps modulate glucose and lipid oxidation, which are favorable for body weight regulation [20-22, 51-53]. Further, dietary fibers prolong satiety and prevent excessive dietary energy intake [23, 24]. The present findings support a positive relationship between energy intake and the odds of general and abdominal obesity. Similarly, in 5 observational studies, positive associations between dietary energy intake and obesity in adults were reported [34-38].

This study has both strengths and weaknesses. An important strength is that it is one of the few studies designed to evaluate the intake of dietary fiber and energy and general and abdominal obesity in a young male population in Ghana. However, the study may have weaknesses. For example, dietary intake was determined by using a 24-hour recall approach. For this method, there was the chance of misreporting of dietary intake due to cognitive challenges such as forgetfulness $[44,54,55]$. However, several measures were taken to enhance the quality of dietary reports by following a standardized multi-pass system [44, 45]. First, participants were asked to mention the names of all foods they consumed in the last 24-hour period of the study. Second, they were allowed to provide more details on the type and preparation of food. Third, the participants also mentioned the quantities of food items consumed. Forth, they were probed for snacks or drinks and other food items that they may have consumed. The multi-pass approach was shown to substantially improve the accuracy of dietary reporting $[56,57]$.

\section{Conclusion}

The study revealed an inverse relationship between dietary consumption and both general and abdominal obesity. Further, the odds of obesity were found to increase directly with dietary energy intake. The findings may be useful in the development of nutrition strategies for the prevention of obesity in the country. The Sissala East municipal health directorate ought to promote the consumption of whole grains and cereal products due to their high fiber content.

\section{Competing Interests}

I declare that there are no competing interests.

\section{Acknowledgements}

I thank all the participants for their participation in the study.

\section{References}

[1] Steyn NP, Mchiza ZJ. Obesity and the nutrition transition in Sub-Saharan Africa. Ann N Y Acad Sci. 2014; 1311: 88-101.

[2] Basu S, McKee M, Galea G, Stuckler D. Relationship of soft drink consumption to global overweight, obesity, and diabetes A cross-national analysis of 75 countries. Am J Public Health. 2013; 103: 2071-7.

[3] Amugsi DA, Mittelmark MB, Oduro A. Association between maternal and child dietary diversity: An analysis of the Ghana Demographic and Health Survey. PLoS One. 2015; 10: $1-12$.

[4] Galbete C, Nicolaou M, Meeks KA, de-Graft Aikins A, Addo J, Amoah SK, et al. Food consumption, nutrient intake, and dietary patterns in Ghanaian migrants in Europe and their compatriots in Ghana. Food Nutr Res. 2017; 61: 1341809.

[5] Ofori-Asenso R, Agyeman AA, Laar A, Boateng D. Overweight and obesity epidemic in Ghana - A systematic review and meta-analysis. BMC Public Health. 2016; 16. doi: 10.1186/s12889-016-3901-4.

[6] O’Neill S, O’Driscoll L. Metabolic syndrome: A closer look at the growing epidemic and its associated pathologies. Obes Rev. 2015; 16: 1-12.

[7] Alberti KGMM, Eckel RH, Grundy SM, Zimmet PZ, Cleeman JI, Donato KA, et al. Harmonizing the Metabolic Syndrome. Circulation. 2009; 120: 1640-5. doi: 10.1161/CIRCULATIONAHA.109.192644.

[8] Mottillo S, Filion KB, Genest J, Joseph L, Pilote L, Poirier P, et al. The metabolic syndrome and cardiovascular risk: A systematic review and meta-analysis. J Am Coll Cardiol. 2010; 56: 1113-32.

[9] Anderson JW, Davidson MH, Blonde L, Brown WV, Howard WJ, Ginsberg H, et al. Long-term cholesterol-lowering effects of psyllium as an adjunct to diet therapy in the treatment of hypercholesterolemia. Am J Clin Nutr. 2000; 71: 1433-8. 
[10] Anderson JW, Hanna TJ. Impact of Nondigestible Carbohydrates on Serum Lipoproteins and Risk for Cardiovascular Disease. J Nutr. 1999; 129: 1457S-1466S.

[11] Romero AL, Romero JE, Galaviz S, Fernandez ML. Cookies Enriched with Psyllium or Oat Bran Lower Plasma LDL Cholesterol in Normal and Hypercholesterolemic Men from Northern Mexico. J Am Coll Nutr. 1998; 17: 601-8.

[12] Chandalia M, Garg A, Lutjohann D, Von Bergmann K, Grundy SM, Brinkley LJ. Beneficial effects of high dietary fiber intake in patients with type 2 diabetes mellitus. N Engl J Med. 2000; 342: 1392-8.

[13] Burke V, Hodgson JM, Beilin LJ, Giangiulioi N, Rogers P, Puddey IB. Dietary protein and soluble fiber reduce ambulatory blood pressure in treated hypertensives. Hypertension. 2001; 38: 821-6.

[14] Jenkins DJA, Kendall CWC, Vuksan V, Vidgen E, Parker T, Faulkner D, et al. Soluble fiber intake at a dose approved by the US Food and Drug Administration for a claim of health benefits: Serum lipid risk factors for cardiovascular disease assessed in a randomized controlled crossover trial. Am J Clin Nutr. 2002; 75: 834-9.

[15] He J, Streiffer RH, Muntner P, Krousel-Wood MA, Whelton PK. Effect of dietary fiber intake on blood pressure: A randomized, double-blind, placebo-controlled trial. J Hypertens. 2004; 22: 73-80.

[16] Aleixandre A, Miguel M. Dietary fiber in the prevention and treatment of metabolic syndrome: A review. Critical Reviews in Food Science and Nutrition. 2008; 48: 905-12.

[17] Chutkan R, Fahey G, Wright WL, Mcrorie J. Viscous versus nonviscous soluble fiber supplements: Mechanisms and evidence for fiber-specific health benefits. Journal of the American Academy of Nurse Practitioners. 2012; 24: 476-87.

[18] Streppel MT, Arends LR, Van't Veer P, Grobbee DE, Geleijnse JM. Dietary fiber and blood pressure: A metaanalysis of randomized placebo-controlled trials. Archives of Internal Medicine. 2005; 165: 150-6.

[19] Brown L, Rosner B, Willett WW, Sacks FM. Cholesterollowering effects of dietary fiber: a meta-analysis. Am J Clin Nutr. 1999; 69: 30-42. doi: 10.1093/ajen/69.1.30.

[20] Sleeth ML, Thompson EL, Ford HE, Zac-Varghese SEK, Frost G. Free fatty acid receptor 2 and nutrient sensing: a proposed role for fibre, fermentable carbohydrates and shortchain fatty acids in appetite regulation. Nutr Res Rev. 2010; 23: $135-45$.

[21] Kasubuchi M, Hasegawa S, Hiramatsu T, Ichimura A, Kimura I. Dietary gut microbial metabolites, short-chain fatty acids, and host metabolic regulation. Nutrients. 2015; 7: 2839-49.

[22] Giacco R, Della Pepa G, Luongo D, Riccardi G. Whole grain intake in relation to body weight: From epidemiological evidence to clinical trials. Nutrition, Metabolism and Cardiovascular Diseases. 2011; 21: 901-8.

[23] Slavin J, Green H. Dietary fibre and satiety. Nutrition Bulletin. 2007; 32 SUPPL. 1: 32-42.

[24] Kristensen M, Jensen MG, Riboldi G, Petronio M, Bügel S, Toubro S, et al. Wholegrain vs. refined wheat bread and pasta. Effect on postprandial glycemia, appetite, and subsequent ad libitum energy intake in young healthy adults. Appetite. 2010;

\section{4: 163-9.}

[25] El-Asfahani AMA, El-Asfahani AMA. Glycemic Index and Glycemic Load: Their Relationship to Adiposity in College Students. J Am Diet Assoc. 2005; 105: 25. doi: 10.1016/j.jada.2005.05.082.

[26] Lin Y, Huybrechts I, Vandevijvere S, Bolca S, De Keyzer W, De Vriese $\mathrm{S}$, et al. Fibre intake among the Belgian population by sexâ€"age and sexâ€"education groups and its association with BMI and waist circumference. Br J Nutr. 2011; 105: $1692-703$.

[27] Kaartinen NE, Knekt P, Kanerva N, Valsta LM, Eriksson JG, Rissanen H, et al. Dietary carbohydrate quantity and quality in relation to obesity: A pooled analysis of three Finnish populationbased studies. Scand J Public Health. 2016; 44: 385-93.

[28] Thompson S V., Hannon BA, An R, Holscher HD. Effects of isolated soluble fiber supplementation on body weight, glycemia, and insulinemia in adults with overweight and obesity: A systematic review and meta-analysis of randomized controlled trials. American Journal of Clinical Nutrition. 2017; 106: $1514-28$.

[29] Kim SH, Hong S Bin, Suh YJ, Choi YJ, Nam M, Lee HW, et al. Association between Nutrient Intake and Obesity in Type 2 Diabetic Patients from the Korean National Diabetes Program: A Cross-Sectional Study. J Korean Med Sci. 2012; 27: 1188. doi: $10.3346 / \mathrm{jkms} .2012 .27 .10 .1188$.

[30] Du H, Van Der A DL, Boshuizen HC, Forouhi NG, Wareham NJ, Halkjær J, et al. Dietary fiber and subsequent changes in body weight and waist circumference in European men and women. Am J Clin Nutr. 2010.

[31] Fujii H, Iwase M, Ohkuma T, Ogata-Kaizu S, Ide H, Kikuchi $\mathrm{Y}$, et al. Impact of dietary fiber intake on glycemic control, cardiovascular risk factors and chronic kidney disease in Japanese patients with type 2 diabetes mellitus: The Fukuoka Diabetes Registry. Nutr J. 2013; 12.

[32] McKeown NM, Yoshida M, Shea MK, Jacques PF, Lichtenstein AH, Rogers $\mathrm{G}$, et al. Whole-Grain Intake and Cereal Fiber Are Associated with Lower Abdominal Adiposity in Older Adults. J Nutr. 2009; 139: 1950-5.

[33] Bell EA, Castellanos VH, Pelkman CL, Thorwart ML, Rolls BJ. Energy density of foods affects energy intake in normalweight women. Am J Clin Nutr. 1998; 67: 412-20. doi: 10.1093/ajcn/67.3.412.

[34] Zhao J, Sun J, Su C. Gender differences in the relationship between dietary energy and macronutrients intake and body weight outcomes in Chinese adults. Nutr J. 2020; 19: 45. doi: 10.1186/s12937-020-00564-6.

[35] Vernarelli JA, Mitchell DC, Rolls BJ, Hartman TJ. Dietary energy density is associated with obesity and other biomarkers of chronic disease in US adults. Eur J Nutr. 2015; 54: 59-65. doi: 10.1007/s00394-014-0685-0.

[36] Chaudhary A. Relationship between dietary intake and prevalence of obesity in children with down's syndrome. Adv Obesity, Weight Manag Control. 2019; 9: 40-2. doi: 10.15406/aowmc.2019.09.00271.

[37] Ebbeling CB. Compensation for Energy Intake From Fast Food Among Overweight and Lean Adolescents. JAMA. 2004; 291: 2828. doi: 10.1001/jama.291.23.2828. 
[38] Mendoza JA, Drewnowski A, Christakis DA. Dietary Energy Density Is Associated With Obesity and the Metabolic Syndrome in U.S. Adults. Diabetes Care. 2007; 30: 974-9. doi: $10.2337 / \mathrm{dc} 06-2188$.

[39] Elliott SA, Truby H, Lee A, Harper C, Abbott RA, Davies PS Associations of body mass index and waist circumference with: energy intake and percentage energy from macronutrients, in a cohort of australian children. Nutr J. 2011; 10: 58. doi: 10.1186/1475-2891-10-58.

[40] Dankwah E, Koduah-Benewaa P. Household Wealth Inequalities in High Body Mass Index among Women of Childbearing Age: Evid.

[41] International Physical Activity Questionniare Group. International physical activity questionnaire short last 7 days self-administered format for use with young and middle aged adults. Res Q Exerc Sport. 2002.

[42] Craig CL, Marshall AL, Sjöström M, Bauman AE, Booth ML, Ainsworth BE, et al. International physical activity questionnaire: 12-Country reliability and validity. Med Sci Sports Exerc. 2003; 35: 1381-95.

[43] Stadlmayr B, Charrondiere R, Enujiugha V, Bayili R, Fagbohoun E, Samb B, et al. West African food composition table [Table de composition des aliments d'Afrique de l'Ouest]. 2012. http: //www.fao.org/3/a-i2698b.pdf.

[44] Briefel RR, Sempos CT, McDowell MA, Chien S, Alaimo K. Dietary methods research in the third National Health and Nutrition Examination Survey: Underreporting of energy intake. In: American Journal of Clinical Nutrition. 1997.

[45] Slimani N, Deharveng G, Charrondière RU, Van Kappel AL, Ocké MC, Welch A, et al. Structure of the standardized computerized 24-h diet recall interview used as reference method in the 22 centers participating in the EPIC project. Comput Methods Programs Biomed. 1999.

[46] World Health Organization. Obesity: preventing and managing the global epidemic. Report of a WHO consultation. World Health Organ Tech Rep Ser. 2000; 894: i-xii, 1-253. http: //www.ncbi.nlm.nih.gov/pubmed/11234459.

[47] World Health Organization. Waist Circumference and WaistHip Ratio Report of a WHO Expert Consultation. 2008.
[48] Kassi E, Pervanidou P, Kaltsas G, Chrousos G. Metabolic syndrome: definitions and controversies. BMC Med. 2011; 9: 48. doi: 10.1186/1741-7015-9-48.

[49] Mogre V, Nyaba R, Aleyira S, Sam NB. Demographic, dietary and physical activity predictors of general and abdominal obesity among university students: a cross-sectional study. Springerplus. 2015; 4: 226. doi: 10.1186/s40064-015-0999-2.

[50] Eli-Cophie D, Agbenorhevi JK, Annan RA. Glycemic index of some local staples in Ghana. Food Sci Nutr. 2017; 5: 131-8.

[51] Sierra M, Garciía JJ, Fernaández N, Diez MJ, Calle AP, Álvarez JC, et al. Therapeutic effects of psyllium in type 2 diabetic patients. Eur J Clin Nutr. 2002; 56: 830-42.

[52] Hanai H, Ikuma M, Sato Y, Iida T, Hosoda Y, Matsushita I, et al. Long-term Effects of Water-soluble Corn Bran Hemicellulose on Glucose Tolerance in Obese and Non-obese Patients: Improved Insulin Sensitivity and Glucose Metabolism in Obese Subjects. Biosci Biotechnol Biochem. 1997; 61: 1358-61.

[53] Pereira MA, Jacobs DR, Pins JJ, Raatz SK, Gross MD, Slavin $\mathrm{JL}$, et al. Effect of whole grains on insulin sensitivity in overweight hyperinsulinemic adults. Am J Clin Nutr. 2002; 75: $848-55$.

[54] Bathalon GP, Tucker KL, Hays NP, Vinken AG, Greenberg AS, McCrory MA, et al. Psychological measures of eating behavior and the accuracy of 3 common dietary assessment methods in healthy postmenopausal women. Am J Clin Nutr. 2000 .

[55] Johansson G, Wikman Å, Åhrén A-M, Hallmans G, Johansson I. Underreporting of energy intake in repeated 24-hour recalls related to gender, age, weight status, day of interview, educational level, reported food intake, smoking habits and area of living. Public Health Nutr. 2001.

[56] Conway JM, Ingwersen LA, Vinyard BT, Moshfegh AJ. Effectiveness of the US Department of Agriculture 5-step multiple-pass method in assessing food intake in obese and nonobese women. Am J Clin Nutr. 2003.

[57] Conway JM, Ingwersen LA, Moshfegh AJ. Accuracy of dietary recall using the USDA five-step multiple-pass method in men: An observational validation study. J Am Diet Assoc. 2004. 